\title{
Pemanfaatan Informasi Teknologi Mangga (Kasus Di Kecamatan Sedong Kabupaten Cirebon)
}

\author{
Utilization of Information of Technology by Mango Farmer \\ (Case of Sedong Subdistrict, Cirebon Regency) \\ Junika Megawaty Pasaribu ${ }^{1}$, Ninuk Purnaningsih ${ }^{2}$, Retno Sri Hartati Mulyandari ${ }^{3}$ \\ ${ }^{1}$ Direktorat Jenderal Hortikultura, Kementerian Pertanian; \\ ${ }^{2}$ Departemen Sains Komunikasi dan Pengembangan Masyarakat, \\ Fakultas Ekologi Manusia, Institut Pertanian Bogor; \\ ${ }^{3}$ Balai Besar Pengkajian Penerapan Teknologi Pertanian, Kementerian Pertanian \\ e-mail: junika_pasaribu@yahoo.com
}

\begin{abstract}
Abstrak
Petani mangga membutuhkan teknologi untuk meningkatkan produksi dan mutu buah. Komunikasi pembangunan berperan penting dalam menyebarkan informasi teknologi tersebut karena dapat meningkatkan pengetahuan dan mendorong petani menerapkannya. Penelitian ini bertujuan untuk menganalisis penggunaan sumber informasi tekologi oleh petani mangga, faktor-faktor yang berhubungan dengan penggunaan informasi teknologi oleh petani mangga, dan menganalisis hubungan penggunaan sumber informasi terhadap tingkat pemanfaatan informasi teknologi oleh petani mangga. Penelitian dengan metode survey dilaksanakan pada 65 responden petani mangga di Kecamatan Sedong Kabupaten Cirebon. Hasil survey menunjukkan bahwa tingkat pemanfaatan informasi teknologi adalah sangat tinggi untuk meningkatkan pengetahuan, sangat rendah untuk dipraktekkan, dan tinggi untuk diteruskan kepada orang lain, faktor yang berpengaruh terhadap penggunaan sumber informasi adalah umur, tingkat pendidikan formal dan non formal, skala usaha, tingkat pendapatan, informasi teknologi budidaya, pasca panen, dan pemasaran, serta tingkat kemudahan dan keterjangkauan biaya, dan penggunaan sumber informasi oleh petani mangga berhubungan sangat nyata dengan pemanfaataan informasi.
\end{abstract}

Kata kunci: pemanfaatan informasi, mangga, kebutuhan informasi, sumber informasi

Abstract

Mango farmer need a technology to improve the production and the quality of mango. This study was aimed to analyse the factors related to the use of information by mango farmer, the relationship of farmer characteristics, level of information need, and level of information access with the use of information sources by the mango farmer, and to analyze the relationship between the use of information sources and the level of utilization of technology information by the mango farmer. A survey was conducted towards 65 farmers as respondents in Sedong Subdistrict, Cirebon Regency.The results showed that in the use of information sources of mango farmer, a few of information sources were used, the intensity of information access was low and the level of information appropriateness were low and very high. The influential factors towards the use of information sources were age, level of formal and non-formal education, scale of business, level of income, level of information need of cultivation, postharvest, and marketing, and so level of easiness and affordability to access information. The level of utilization of information were very high to enhance the knowledge, very low to be applicated, and high to be forwarded to others. A very significant possitive correlation was found between the use of information sources and utilization of information.

Keywords: utilization of information, mango, information need, information sources 
ISSN 1693-3699 (Cetak)

ISSN 2442-4102

\section{PENDAHULUAN}

Mangga adalah buah bernilai ekonomi tinggi karena dapat diandalkan sebagai sumber pendapatan petani dan devisa negara. Indonesia adalah negara penghasil mangga ke-5 terbesar di dunia, namun berkontribusi kurang dari 0.1 persen dari total ekspor mangga dunia (FAOSTAT 2014). Permasalahan dalam pengembangan mangga adalah produktivitas dan mutu tanaman yang belum optimal (DJH 2013), untuk mengatasinya diperlukan penerapan teknologi. Peran teknologi sangat penting dalam era globalisasi saat ini, karena petani tidak hanya dituntut mampu bersaing dalam produksi tetapi juga dalam hal mutu dan harga (Ellitan dan Anatan 2009).

Pemerintah melakukan berbagai upaya untuk pengembangan komoditas mangga, seperti perluasan areal tanam, kegiatan penelitian dan pengkajian, bantuan sarana produksi, infrastruktur, perbenihan, peningkatan pengetahuan dan kemampuan petani dalam hal teknologi, dan lain-lain. Namun upaya tersebut belum berhasil dengan baik, karena permintaan ekspor buah mangga masih banyak yang belum dapat dipenuhi terkendala persyaratan mutu.

Komunikasi pembangunan berperan sangat penting baik dalam penyebaran dan pemahaman informasi teknologi, maupun penerapannya oleh para petani mangga. Menurut Adedokun et al. (2010) potensi pembangunan hanya dapat terwujud jika pengetahuan dan teknologi disebarkan secara efektif dan masyarakat pedesaan yang terlibat dalam proses dapat termotivasi untuk mencapai keberhasilan.

Okwu dan Umoru (2009) dan

Andriaty dan Setyorini (2012) menyatakan bahwa jenis informasi yang
Jurnal Komunikasi Pembangunan Juli 2015. Vol.13, No.2

diperlukan petani umumnya berkaitan dengan produksi dan teknologi pertanian. Mulyandari (2011) menyatakan informasi teknik produksi dan pemasaran telah dipublikasikan di berbagai media, namun masih banyak petani yang luput dari penyebaran dan penyediaan informasi pertanian.

Ma'mir (2001) menyatakan bahwa kebutuhan informasi petani berhubungan nyata dengan perilaku pemanfaatan informasi. Selanjutnya Andriaty dan Setyorini (2012) menyatakan semakin tinggi tingkat kebutuhan informasi maka semakin tinggi pula tingkat manfaat yang diperoleh dari berbagai sumber informasi, baik itu melalui media pertemuan (tatap muka), cetak maupun elektronik. Penelitian Asmawati (2013) menunjukkan bahwa pemanfaatan informasi berhubungan dengan penggunaan sumber informasi. Menurut Babu et al. (2012) dengan memahami bagaimana petani mengakses dan menggunakan informasi, kebutuhan informasi petani, dan faktor perilaku pencarian informasi maka penyebaran informasi pertanian dapat sampai ke petani dengan lebih baik. Akses terhadap informasi tidak sama pada seluruh masyarakat (Moore 2007). Menurut Andriaty et al. (2011) kemudahan akses terhadap informasi antara lain didukung oleh infrastruktur dan kedekatan daerah (jarak domisili) dengan pusat pemerintahan dan kegiatan ekonomi.

Penelitian ini bertujuan untuk: (1) menganalisis karakterisitik individu, kebutuhan informasi, tingkat akses informasi dan penggunaan sumber informasi oleh petani mangga, (2) menganalisis faktor-faktor yang berhubungan dengan penggunaan sumber informasi oleh petani mangga, (3) menganalisis pemanfaatan informasi 
oleh petani mangga, (4) menganalisis hubungan antara penggunaan sumber informasi dengan pemanfaatan informasi oleh petani mangga.

\section{Metode Penelitian}

Penelitian dilaksanakan di Desa Sedong Lor dan Winduhaji yang terletak di Kecamatan Sedong, Kabupaten Cirebon, Propinsi Jawa Barat. Penentuan desa dilakukan secara purposive berdasarkan tingkat aksesibilitas terhadap informasi dengan kriteria jarak desa ke ibukota kecamatan Sedong dan pasar Sedong. Desa Sedong Lor merupakan desa yang tingkat aksesibilitasnya baik terhadap informasi dan Desa Winduhaji yang tingkat aksesibilitasnya relatif kurang baik. Pengambilan data dilaksanakan bulan Mei-Juni 2014. Responden penelitian adalah seluruh anggota kelompok tani mangga yang ada di kedua desa, yaitu 30 petani di Desa Sedong Lor dan 35 petani di Desa Winduhaji, sehingga total terdapat 65 orang responden. Data primer diperoleh melalui observasi dan wawancara kepada responden dan informan dengan menggunakan kuesioner yang sudah diuji validitas dan reliabilitasnya. Data sekunder diperoleh dari instansi terkait. Data hasil kuesioner dianalisis dengan statistik deskriptif dan inferensial dengan uji korelasi rank Spearman dan uji beda ( $t$ test).

\section{HASIL DAN PEMBAHASAN}

\section{Karakteristik Petani}

Karakteristik petani mangga, yaitu umur, pendidikan formal dan non formal, skala usaha, pengalaman berusaha tani, dan pendapatan. secara ringkas disajikan pada Tabel 1. Umur petani mangga di kedua desa didominasi oleh petani dewasa yang berusia 43-54 tahun (36.92 persen). Menurut Saputra (2007) usia produktif adalah 15-64 tahun. Berdasarkan batasan tersebut maka sebagian besar petani responden masih masuk dalam kategori usia kerja produktif yang memiliki kemampuan bekerja serta mencari dan memanfaatkan informasi yang lebih baik dibandingkan usia yang lebih tua. Sebagian besar tingkat pendidikan petani mangga masih rendah, karena lebih dari separuh responden (52.3 persen) hanya berpendidikan formal sampai tingkat SD. Petani yang berpendidikan SD umumnya adalah petani yang berusia dewasa dan tua, sedangkan petani yang berusia muda sudah tamat SMP atau SMA. Tingkat pendidikan non formal petani sebagian besar masuk dalam kategori jarang (38.46 persen). Hasil uji beda menunjukkan tingkat pendidikan non formal petani di kedua desa berbeda nyata $(\mathrm{p}<0.05)$. 
Tabel 1 Karakteristik individu petani mangga

\begin{tabular}{|c|c|c|c|c|c|}
\hline \multirow[b]{2}{*}{ Karakteristik individu } & & \multicolumn{3}{|c|}{ Jumlah petani (\%) } & \multirow{2}{*}{$\begin{array}{l}\text { thitung } \\
\text { (Sig.) }\end{array}$} \\
\hline & & $\begin{array}{c}\text { Sedong Lor } \\
(\mathrm{n}=30)\end{array}$ & $\begin{array}{c}\text { Winduhaji } \\
(\mathrm{n}=35)\end{array}$ & $\begin{array}{l}\text { Total } \\
(\mathrm{n}=65)\end{array}$ & \\
\hline \multicolumn{6}{|l|}{ Umur (tahun) } \\
\hline Muda & $(30-42)$ & 26.67 & 28.57 & 27.69 & 0.639 \\
\hline Dewasa & $(43-54)$ & 36.67 & 37.14 & 36.92 & $(0.525)$ \\
\hline Tua & $(55-79)$ & 36.67 & 34.29 & 35.39 & \\
\hline \multicolumn{6}{|l|}{ Pendidikan formal (tahun) } \\
\hline SD & $(3-6)$ & 40.00 & 62.86 & 52.31 & 1.911 \\
\hline SMP & $(7-9)$ & 26.67 & 20.00 & 23.08 & $(0.061)$ \\
\hline SMA & $(10-12)$ & 30.00 & 17.14 & 23.08 & \\
\hline PT & $(13-15)$ & 3.33 & 0.00 & 1.54 & \\
\hline \multicolumn{6}{|l|}{ Pendidikan non formal (kali) } \\
\hline Sangat jarang & $(1-2)$ & 20.00 & 37.14 & 29.23 & $2.325^{*}$ \\
\hline Jarang & (3) & 33.33 & 42.86 & 38.46 & $(0.023)$ \\
\hline Sering & (4) & 33.33 & 11.43 & 21.54 & \\
\hline Sangat sering & $(5-6)$ & 13.33 & 8.57 & 10.77 & \\
\hline \multicolumn{6}{|l|}{ Pengalaman (tahun) } \\
\hline Sedikit & $(8-10)$ & 3.33 & 17.14 & 10.77 & 1.416 \\
\hline Cukup & $(11-12)$ & 43.33 & 37.14 & 40 & $(0.162)$ \\
\hline Berpengalaman & $(13-14)$ & 26.67 & 34.29 & 30.77 & \\
\hline Sangat berpengalaman & $(15-17)$ & 26.67 & 11.43 & 18.46 & \\
\hline \multicolumn{6}{|l|}{ Skala usaha (pohon) } \\
\hline Sangat kecil & $(12-39)$ & 43.33 & 77.14 & 61.54 & $2.016^{*}$ \\
\hline Kecil & $(40-66)$ & 30.00 & 14.29 & 21.54 & 0.048 \\
\hline Besar & $(67-93)$ & 6.67 & 0.00 & 3.08 & \\
\hline Sangat besar & $(94-900)$ & 20.00 & 8.57 & 13.85 & \\
\hline \multicolumn{6}{|l|}{ Tingkat pendapatan (Rp juta) } \\
\hline Sangat rendah & $(1.0-2.5)$ & 56.67 & 80.00 & 69.23 & 1.76 \\
\hline Rendah & $(2.6-4.0)$ & 23.33 & 14.29 & 18.46 & $(0.083)$ \\
\hline Tinggi & $(4.1-5.5)$ & 10.00 & 2.86 & 6.15 & \\
\hline Sangat tinggi & $(5.6-7.0)$ & 10.00 & 2.86 & 6.15 & \\
\hline
\end{tabular}

Keterangan: * Berbeda nyata pada $\mathrm{p}<0.05$

Sebanyak 40.00 persen petani masuk dalam kategori cukup berpengalaman. Petani yang sangat berpengalaman tidak banyak jumlahnya, yaitu sebanyak 18.46 persen. Hal ini karena petani yang sangat berpengalaman sebagian sudah tidak tinggal di desa karena tinggal dengan anak mereka di luar desa, menyewakan tanaman mangga mereka kepada orang lain karena sudah tidak sanggup memelihara tanaman mangganya, atau karena sudah meninggal dunia.

Data skala usaha petani menunjukkan bahwa jumlah tanaman mangga yang dimiliki petani sangat bervariasi (12-900 pohon). Sebagian besar petani di kedua desa (61.54 persen) berskala usaha kecil (12-39 pohon). Hasil uji beda menunjukkan skala usaha petani di kedua desa berbeda nyata $(\mathrm{p}<0.05)$. Skala usaha petani mangga Sedong Lor lebih besar daripada petani Winduhaji. Tingkat pendapatan petani dalam penelitian ini diukur berdasarkan besarnya rata-rata pengeluaran petani per bulan. Sebagian besar tingkat pendapatan petani masuk dalam kategori sangat rendah yaitu Rp.1 000 000-2 500000 (69.23 persen). 


\section{Tingkat Kebutuhan Informasi}

Tingkat kebutuhan informasi teknologi budidaya, pasca panen, dan pemasaran dari sebagian besar petani mangga masuk dalam kategori tinggi dengan jumlah petani masing-masing 92.31, 60.00, 75.39 persen (Tabel 2). Hal ini menunjukkan bahwa penyebaran informasi teknologi budidaya mangga yang selama ini dilakukan tampaknya masih belum memenuhi kebutuhan informasi sebagian besar petani. Tingkat kebutuhan informasi teknologi petani di kedua desa tidak berbeda nyata ( $p>0.05)$.

Tabel 2 Jumlah petani dan uji beda berdasarkan kebutuhan informasi teknologi

\begin{tabular}{|c|c|c|c|c|}
\hline \multirow{2}{*}{$\begin{array}{l}\text { Tingkat informasi } \\
\text { teknologi }\end{array}$} & \multicolumn{3}{|c|}{ Jumlah petani (\%) } & \multirow{2}{*}{$\begin{array}{l}\mathrm{t}_{\text {hitung }} \\
\text { (Sig.) }\end{array}$} \\
\hline & Sedong Lor $(\mathrm{n}=30)$ & Windu Haji $(\mathrm{n}=35)$ & Total $(n=65)$ & \\
\hline \multicolumn{5}{|l|}{ Budidaya } \\
\hline Rendah & 6.67 & 8.57 & 7.69 & 1.621 \\
\hline Tinggi & 93.33 & 91.43 & 92.31 & $(0.11)$ \\
\hline \multicolumn{5}{|l|}{ Pascapanen } \\
\hline Rendah & 33.34 & 45.72 & 40.00 & 1.153 \\
\hline Tinggi & 66.67 & 54.28 & 60.00 & $(0.253)$ \\
\hline \multicolumn{5}{|l|}{ Pemasaran } \\
\hline Rendah & 23.33 & 25.71 & 24.61 & -0.057 \\
\hline Tinggi & 76.66 & 74.28 & 75.39 & $(0.955)$ \\
\hline
\end{tabular}

Jenis informasi yang sangat dibutuhkan oleh sebagian besar petani adalah informasi pengendalian hama dan penyakit tanaman atau HPT (87.69 persen), lalu diikuti pemupukan (86.15 persen), off season (75.38 persen), harga (70.77 persen), dan pembeli (63.08 persen). Petani tampaknya masih sangat membutuhkan informasi pengendalian HPT dan pemupukan, meskipun informasi tersebut sudah relatif sering disampaikan pada saat pelatihan atau pertemuan kelompok. Petani mengharapkan ada rekomendasi pemupukan yang dapat meningkatkan produksi buah, tetapi harganya murah dan mudah diperoleh. Aurenhammer (Faroka et al. 2013) menyatakan bahwa petani mengharapkan teknologi baru yang dapat menurunkan penggunaan pupuk sebesar dua kali lipat tetapi hasil panen relatif sama dengan hasil panen biasanya. Dalam hal pemasaran mangga, petani tidak mengalami kesulitan, namun mereka menyatakan sangat membutuhkan informasi pemasaran. Hal ini menunjukkan petani belum puas dengan harga yang selama ini diterimanya.

\section{Tingkat Akses Informasi}

Akses terhadap informasi teknologi pertanian dan pasar menjadi hal yang sangat penting demi kelangsungan usaha tani (Saleh dan Mulyandari 2011). Proses diseminasi informasi memerlukan informasi hasilhasil penelitian dan pemasaran produk pertanian yang dapat diakses oleh petani dengan mudah dan dengan biaya terjangkau.

Tabel 3 menunjukkan bahwa sebagian besar petani Desa Sedong Lor mudah mengakses media interpersonal (70.00 persen) sedangkan petani Winduhaji menilai sulit (77.15 persen). Sebagian besar petani Desa Sedong Lor (63.33 persen) dan Winduhaji (82.86 persen) menilai sulit mengakses media cetak. Selanjutnya, sebagian besar petani di kedua desa, Desa Sedong Lor (56.66 persen) dan Winduhaji (85.72 
persen) menilai sulit mengakses media elektronik. Kondisi ini terjadi karena desa Sedong Lor lebih sering dikunjungi petugas pertanian dan sering dijadikan tempat pelatihan, pertemuan, dan lokasi penelitian, sehingga petani lebih mudah bertemu para petugas, peneliti, sesama petani mangga, eksportir, dan pihak-pihak lain yang terkait dengan usaha tani mangga dan lebih sering mendapatkan buku, leaflet, dan poster. Hasil uji beda menunjukkan bahwa tingkat kemudahan akses media interpersonal berbeda sangat nyata $(\mathrm{p}<0.01)$ dan kemudahan akses media cetak berbeda nyata $(\mathrm{p}<0.05)$, sedangkan kemudahan akses media elektronik tidak berbeda nyata.

Tabel 3 Jumlah petani dan uji beda rata-rata berdasarkan tingkat akses informasi

\begin{tabular}{|c|c|c|c|c|c|c|c|c|c|}
\hline \multirow{3}{*}{$\begin{array}{l}\text { Tingkat } \\
\text { akses } \\
\text { informasi }\end{array}$} & \multicolumn{9}{|c|}{ Jumlah petani (\%) } \\
\hline & \multicolumn{3}{|c|}{ Media interpersonal } & \multicolumn{3}{|c|}{ Media cetak } & \multicolumn{3}{|c|}{ Media elektronik } \\
\hline & SL & $\mathrm{W}$ & Total & SL & $\mathrm{W}$ & Total & SL & $\mathrm{W}$ & Total \\
\hline \multicolumn{10}{|c|}{ Kemudahan akses } \\
\hline Sulit & 30.00 & 77.15 & 55.38 & 63.33 & 82.86 & 73.84 & 53.33 & 71.42 & 63.08 \\
\hline Mudah & 70.00 & 22.86 & 44.61 & 36.66 & 17.15 & 26.15 & 46.67 & 28.57 & 36.92 \\
\hline $\mathrm{t}_{\text {hitung (Sig.) }}$ & \multicolumn{3}{|c|}{$3.839 * *(0.000)$} & \multicolumn{3}{|c|}{$1.997 *(0.049)$} & \multicolumn{3}{|c|}{$1.757(0.084)$} \\
\hline \multicolumn{10}{|c|}{ Keterjangkauan biaya } \\
\hline Mahal & 13.33 & 51.43 & 33.84 & 46.67 & 71.43 & 60.00 & 83.33 & 85.72 & 84.61 \\
\hline Murah & 86.67 & 48.57 & 66.15 & 53.33 & 28.57 & 40.00 & 16.67 & 14.28 & 15.38 \\
\hline $\mathrm{t}_{\text {hitung (Sig.) }}$ & \multicolumn{3}{|c|}{$3.685 * *(0.000)$} & \multicolumn{3}{|c|}{$2.410 *(0.019)$} & \multicolumn{3}{|c|}{$0.432(0.667)$} \\
\hline
\end{tabular}

Keterangan: * Berbeda nyata pada $\mathrm{p}<0.05 ; * *$ Berbeda sangat nyata pada $\mathrm{p}<0.01$

Umumnya petani Desa Sedong Lor menilai biaya akses media interpersonal murah (86.67 persen) dan petani Desa Winduhaji menilai mahal (51.43 persen), demikian juga dalam mengakses media cetak, umumnya petani Desa Sedong Lor menilai murah (53.33 persen) dan petani Winduhaji menilai mahal (71.43 persen). Lokasi Desa Sedong Lor yang lebih dekat dengan pusat kota menyebabkan biaya akses media interpersonal dan cetak lebih murah. Hal ini sesuai dengan $\underline{\text { Kifli }}$ (2007) bahwa lokasi di mana seseorang berada sangat mempengaruhi aspek tingkat aksesibilitasnya. Selanjutnya sebagian besar petani di Desa Sedong Lor (83.33 persen) dan Winduhaji (85.72 persen) menilai mahal mengakses media elektronik. Hal ini karena petani tidak memiliki sarana komunikasi seperti radio, pemutar
DVD, dan komputer serta biaya akses internet yang cukup mahal.

\section{Penggunaan Sumber Informasi}

Sumber informasi yang dimaksud adalah media yang digunakan oleh petani untuk memperoleh informasi teknologi, yaitu media interpersonal (petugas pertanian, sesama petani, eksportir, penyedia saprotan, dan pedagang pengumpul), cetak (koran, buku, majalah, folder, dan poster), dan elektronik ( $\mathrm{TV}$, radio, internet, dan film/DVD).

Berdasarkan keseluruhan media yang digunakan (Tabel 4), sebagian besar petani di kedua desa tergolong sedikit menggunakan sumber informasi yaitu 5-7 sumber (66.15 persen). Hapsari (2012) menemukan hal yang sama bahwa sebagian besar petani berkategori rendah dalam menggunakan sumber informasi. 
Sebagian besar petani mangga menggunakan banyak media interpersonal (81.54 persen), sedikit media cetak (55.38 persen), dan sedikit media elektronik (44.62 persen). Hal ini menunjukkan bahwa petani belum maksimal menggunakan sumber informasi dari media cetak dan elektronik.

Petani mangga menggunakan kombinasi media interpersonal, cetak, dan elektronik sebagai sumber informasi. Hasil penelitian Bardon et al. (2007) terhadap peternak sapi di Northwest Florida juga menunjukkan bahwa peternak menggunakan kombinasi media sebagai sumber informasi (5 kombinasi). Hal ini sesuai dengan Opara (2008) bahwa media yang terbaik adalah yang menggunakan kombinasi saluran.

Tabel 4 Jumlah petani dan uji beda rata-rata berdasarkan penggunaan sumber informasi

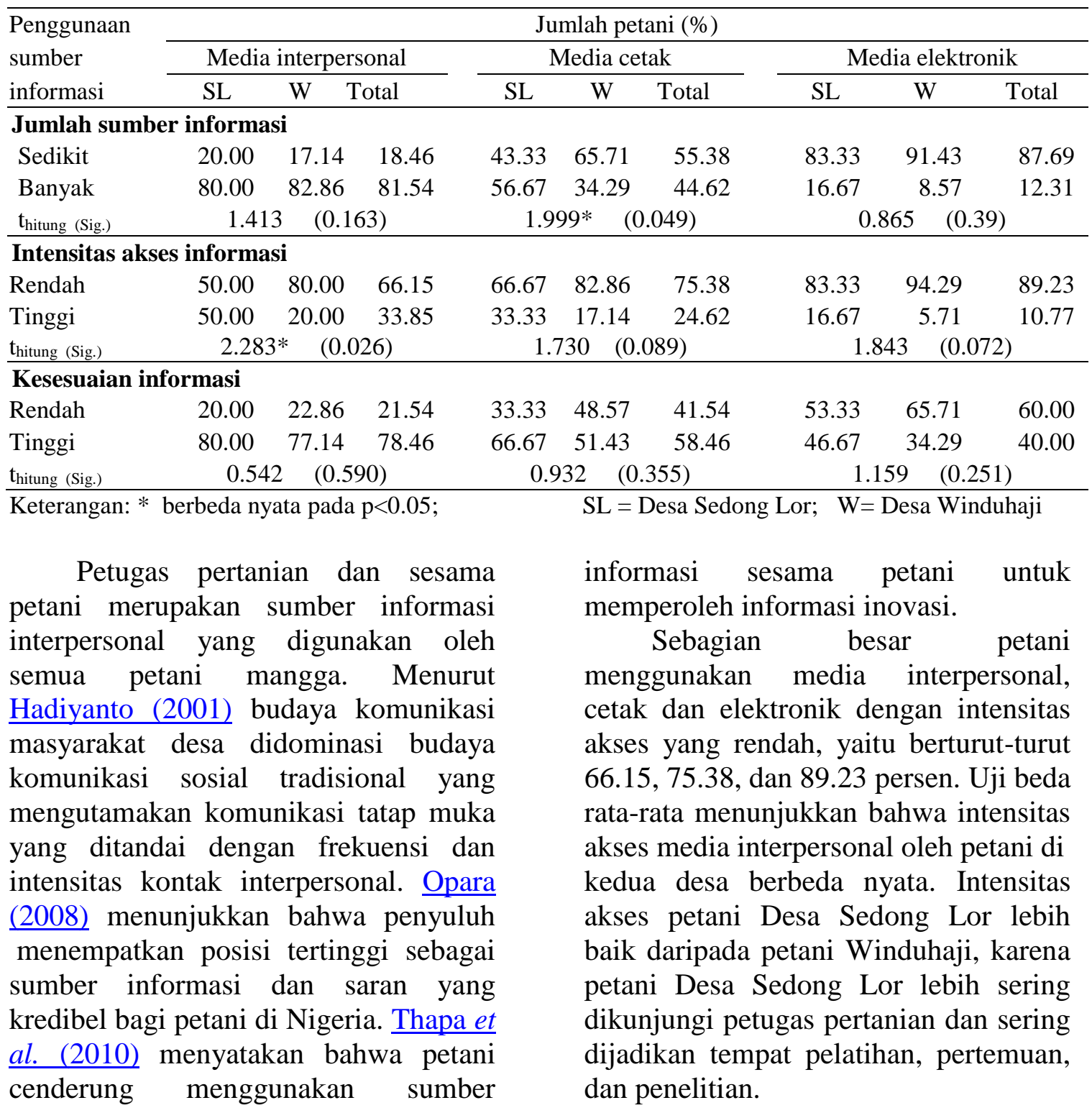


Informasi yang diperoleh melalui media interpersonal dan cetak dinilai oleh sebagian besar petani memiliki tingkat kesesuaian sumber informasi yang tinggi (78.46 dan 58.46 persen) dengan kebutuhan informasi teknologi petani, sedangkan tingkat kesesuaian sumber informasi melalui media elektronik rendah (60.00 persen). Hal ini menunjukkan bahwa informasi yang diperoleh melalui media interpersonal (petugas pertanian dan sesama petani) dan media cetak (buku, folder/poster) sesuai dengan kebutuhan informasi petani, sedangkan informasi melalui media elektronik (TV dan radio) kurang memenuhi kebutuhan informasi petani, karena TV dan radio lebih banyak berisi acara yang sifatnya hiburan, seperti sinetron, film, musik, dan lain-lain.

\section{Hubungan Karakteristik Individu dengan Penggunaan Sumber Informasi}

Tabel 5 memperlihatkan bahwa umur berhubungan sangat nyata dan negatif dengan penggunaan sumber informasi dalam hal jumlah sumber informasi yang diakses dan intensitas akses, serta berhubungan nyata dan negatif dengan tingkat kesesuaian informasi. Artinya semakin bertambah umur petani maka jumlah sumber informasi yang diakses, intensitas mengakses informasi, dan tingkat kesesuaian informasi semakin rendah. Umur yang semakin tua akan menyebabkan seseorang semakin lemah daya biologis dan psikologis, tingkat kepekaan dan potensi-potensi diri lainnya termasuk dalam menggunakan sumber informasi. Semakin tua petani maka maka tingkat kesesuaian informasinya semakin rendah. Hal ini karena petani yang sudah tua menganggap sudah tidak membutuhkan informasi teknologi budidaya dan pasca panen karena mereka sudah terbiasa dengan cara pengelolaan tanaman yang selama ini dilakukan, takut gagal jika menerapkan inovasi teknologi, atau tidak punya tenaga melakukan pemeliharaan intensif. Petani yang lebih tua biasanya kurang bersemangat menerima hal-hal baru dibandingkan mereka yang relatif muda. Andriaty et al. (2011) menemukan hal yang sama bahwa umur berhubungan nyata dan negatif dengan penggunaan sumber informasi.

Tabel 5 Hubungan antara karakteristik individu dengan penggunaan sumber informasi

\begin{tabular}{lccc}
\hline Karakteristik individu & \multicolumn{3}{c}{ Penggunaan sumber informasi } \\
\cline { 2 - 4 } & $\begin{array}{c}\text { Jumlah sumber } \\
\text { informasi yang } \\
\text { diakses }\end{array}$ & $\begin{array}{c}\text { Intensitas akses } \\
\text { informasi }\end{array}$ & $\begin{array}{c}\text { Kesesuaian sumber } \\
\text { informasi }\end{array}$ \\
\hline Umur & $-0.405^{* *}$ & $-0.334^{* *}$ & $-0.267^{*}$ \\
Pendidikan formal & $0.539^{* *}$ & $0.517^{* *}$ & $0.314^{*}$ \\
Pendidikan non formal & $0.356^{* *}$ & $0.391^{* *}$ & 0.155 \\
Pengalaman berusaha tani & -0.053 & 0.007 & 0.007 \\
Skala usaha & $0.559^{* *}$ & $0.586^{* *}$ & $0.438^{* *}$ \\
Pendapatan & $0.580^{* *}$ & $0.618^{* *}$ & $0.470^{* *}$ \\
\hline
\end{tabular}

Ket: * Berhubungan nyata pada $\mathrm{p}<0.05$; ** Berhubungan sangat nyata pada $\mathrm{p}<0.01$

Tingkat pendidikan formal dan non formal, skala usaha, dan pendapatan berhubungan sangat nyata dan positif dengan jumlah sumber informasi yang diakses dan intensitas mengakses informasi. Artinya semakin 
tinggi tingkat pendidikan formal dan non formal, skala usaha dan pendapatan maka jumlah sumber informasi yang diakses semakin banyak dan intensitas mengakses informasi semakin sering. Selanjutnya tingkat pendidikan formal berhubungan nyata dengan kesesuaian informasi, sedangkan skala usaha dan pendapatan berhubungan sangat nyata dengan kesesuaian informasi. Artinya semakin tinggi tingkat pendidikan formal, skala usaha dan pendapatan maka tingkat kesesuaian informasi semakin tinggi. Semakin tinggi pendidikan, skala usaha dan pendapatan petani maka akan semakin mampu mencari dan menyeleksi informasi yang sesuai dengan kebutuhannya.

\section{Hubungan Tingkat Kebutuhan Informasi dengan Penggunaan Sumber Informasi}

Tabel 6 memperlihatkan bahwa kebutuhan informasi teknologi budidaya berhubungan sangat nyata dengan jumlah sumber informasi yang digunakan, berhubungan nyata dengan intensitas akses informasi, dan tidak berhubungan nyata dengan tingkat kesesuaian informasi. Informasi teknologi pasca panen berhubungan sangat nyata dengan jumlah sumber informasi yang digunakan dan intensitas mengakses informasi. Artinya semakin tinggi tingkat kebutuhan petani terhadap informasi teknologi budidaya dan pasca panen maka jumlah sumber informasi dan intensitas mengakses informasi semakin tinggi. Menurut Rogers dan Shoemaker (1995) seseorang yang sadar dan merasakan adanya kebutuhan atau masalah akan berusaha mencari keterangan mengenai hal-hal baru/inovasi untuk memenuhi kebutuhannya. John et al. (2013) menyatakan banyak kasus yang menunjukkan bahwa tingkat kepuasan petani sangat rendah dalam mendapatkan informasi pertanian. Selanjutnya kebutuhan informasi pemasaran berhubungan nyata dengan tingkat kesesuaian informasi tetapi tidak berhubungan nyata dengan jumlah sumber informasi dan intensitas akses informasi. Artinya tinggi rendahnya kebutuhan informasi pemasaran tidak berhubungan dengan jumlah sumber dan intensitas akses informasi, namun semakin tinggi tingkat kebutuhan informasi pemasaran maka tingkat kesesuaian informasi akan semakin tinggi.

Tabel 6 Hubungan tingkat kebutuhan informasi dengan penggunaan sumber informasi

\begin{tabular}{lccc}
\hline Tingkat kebutuhan & \multicolumn{3}{c}{ Penggunaan sumber informasi } \\
\cline { 2 - 4 } & $\begin{array}{c}\text { Jumlah sumber } \\
\text { informasi yang } \\
\text { diakses }\end{array}$ & $\begin{array}{c}\text { Intensitas akses } \\
\text { informasi }\end{array}$ & $\begin{array}{c}\text { Kesesuaian sumber } \\
\text { informasi }\end{array}$ \\
\hline Budidaya & $0.379^{* *}$ & $0.281^{*}$ & 0.176 \\
Pasca panen & $0.577^{* *}$ & $0.579^{* *}$ & $0.377^{* *}$ \\
Pemasaran & 0.209 & 0.145 & $0.261^{*}$
\end{tabular}

Ket: * Berhubungan nyata pada $\mathrm{p}<0.05$; ** Berhubungan sangat nyata pada $\mathrm{p}<0.01$

\section{Hubungan Tingkat Akses Informasi dengan Penggunaan Sumber Informasi}

Kemudahan akses dan keterjangkauan biaya berhubungan sangat nyata dengan penggunaan sumber informasi (jumlah sumber informasi yang diakses, intensitas mengakses informasi dan tingkat kesesuaian informasi). Artinya semakin 
tinggi tingkat kemudahan dan keterjangkauan biaya mengakses informasi maka penggunaan sumber informasi (jumlah sumber informasi yang diakses, intensitas mengakses informasi dan tingkat kesesuaian informasi) semakin tinggi. Hal ini sesuai Andriaty et al. (2011) bahwa kemudahan akses terhadap media komunikasi tertentu mengakibatkan semakin banyak media informasi yang dipilih dan membuat media tersebut semakin sering diakses. Bila dicermati lebih lanjut semua petani menggunakan petugas pertanian dan sesama petani sebagai sumber informasi yang paling mudah diakses dan terjangkau biayanya. Menurut Kifli (2002) keterbatasan biaya menyebabkan petani sulit mengakses dan memanfaatkan informasi pertanian dari media massa, sehingga petani lebih banyak mencari informasi melalui interaksi dan komunikasi dengan PPL dan petani lainnya.

Tabel 7 Hubungan antara tingkat akses informasi dengan penggunaan sumber informasi

\begin{tabular}{lccc}
\hline Tingkat akses & \multicolumn{3}{c}{ Penggunaan sumber informasi } \\
\cline { 2 - 4 } & $\begin{array}{c}\text { Jumlah sumber } \\
\text { informasi yang diakses }\end{array}$ & $\begin{array}{c}\text { Intensitas akses } \\
\text { informasi }\end{array}$ & $\begin{array}{c}\text { Kesesuaian } \\
\text { sumber informasi }\end{array}$ \\
\hline Kemudahan akses & $0.637^{* *}$ & $0.595^{* *}$ & $0.454^{* *}$ \\
Keterjangkauan biaya & $0.551^{* *}$ & $0.665^{* *}$ & $0.486^{* *}$ \\
\hline
\end{tabular}

Ket: ** Berhubungan sangat nyata pada $\mathrm{p}<0.01$

\section{Pemanfaatan Informasi}

Pemanfaatan informasi adalah efek dari informasi yang sudah diterima atau diakses. Pemanfaatan informasi pada penelitian ini diukur berdasarkan pemanfaatan untuk meningkatkan pengetahuan, dipraktekkan dan diteruskan kepada petani lain. Tabel 8 memperlihatkan bahwa sebagian besar petani (80.00 persen), dalam kategori tinggi dalam pemanfaatkan informasi untuk meningkatkan pengetahuan (1013 informasi), sebagian besar petani (20.00 persen) masuk dalam kategori rendah dalam mempraktekkan informasi teknologi dan sebagian besar petani (53.85 persen) masuk dalam kategori rendah dalam meneruskan informasi kepada orang lain.

Tabel 8 Jumlah petani dan uji beda rata-rata berdasarkan tingkat pemanfaatan informasi

\begin{tabular}{|c|c|c|c|c|c|}
\hline \multirow{2}{*}{\multicolumn{2}{|c|}{ Tingkat pemanfaatan }} & \multicolumn{3}{|c|}{ Jumlah petani (\%) } & \multirow{2}{*}{$\begin{array}{l}\text { thitung } \\
\text { (Sig.) }\end{array}$} \\
\hline & & $\begin{array}{l}\text { Sedong Lor } \\
(\mathrm{n}=30)\end{array}$ & $\begin{array}{l}\text { Windu } \\
\text { haji } \\
(\mathrm{n}=35)\end{array}$ & $\begin{array}{l}\text { Total } \\
(n=65)\end{array}$ & \\
\hline \multicolumn{6}{|c|}{ Meningkatkan pengetahuan } \\
\hline Rendah & (5-9 informasi) & 10.00 & 28.58 & 20.00 & $2.572 * *$ \\
\hline Tinggi & (10-13 informasi) & 90.00 & 71.43 & 80.00 & 0.013 \\
\hline \multicolumn{6}{|c|}{ Dipraktekkan } \\
\hline Rendah & (3-8 informasi) & 36.67 & 74.29 & 56.92 & $2.159 *$ \\
\hline Tinggi & (9-13 informasi) & 63.33 & 25.71 & 43.08 & 0.035 \\
\hline \multicolumn{6}{|c|}{ Diteruskan kepada orang lain } \\
\hline Rendah & (2-7 informasi) & 43.33 & 62.85 & 53.85 & 1.59 \\
\hline Tinggi & (8-13 informasi) & 56.67 & 37.14 & 46.15 & 0.117 \\
\hline
\end{tabular}


Informasi harga dan pembeli bermanfaat sebagai pengetahuan bagi semua petani. Informasi bibit, sortasi, pemangkasan dan pemupukan bermanfaat sebagai pengetahuan bagi lebih dari 90.00 persen petani. Pengetahuan adalah salah satu dasar penilaian terhadap layak atau tidaknya penerapan suatu teknologi usaha tani.

Informasi pemupukan, panen, pemangkasan, pengendalian HPT, dan sortasi dipraktekkan oleh lebih dari separuh petani responden. Informasi yang paling sedikit dipraktekkan oleh petani adalah penjarangan ( 7.69 persen) dan pembungkusan buah (16.92 persen). Informasi harga dan pembeli digunakan oleh semua petani pada saat memasarkan mangga. Informasi bibit dipraktekkan oleh semua petani, karena bibit yang ditanam petani adalah bantuan pemerintah yang sudah bersertifikat. Dari hasil wawancara diketahui bahwa penerapan informasi teknologi oleh petani dipengaruhi faktor jenis teknologi, modal petani, dan keuntungan yang akan diperoleh. Babu et al. (2012) menyatakan alasan utama petani tidak menerapkan informasi adalah karena informasi tidak bermanfaat, kurang saran teknis untuk tindak lanjut, dan tidak jelas. Faktorfaktor yang mempengaruhi keputusan petani dalam mengadosi inovasi menurut Purnaningsih et al. (2006) antara lain tingkat kepastian pasar dari produk yang dihasilkan, tingkat kebutuhan inovasi, dan ketersediaan sarana transportasi. Penelitian Mulyadi et al. (2007) menunjukkan bahwa petani sulit mengadopsi inovasi yang tidak dibutuhkan dan tidak sesuai dengan teknologi lokal, sehingga kesesuaian inovasi dengan kebutuhan dan sosial budaya setempat sangat penting diperhatikan.
Petani mangga seperti halnya masyarakat lainnya biasa saling memberi dan menerima informasi tentang usahatani mangga. Penelitian Agunga dan Igodan (2007) menunjukkan hal yang sama bahwa petani organik ingin belajar satu sama lain atau membagikan pengalamannya dengan petani lain. Informasi yang paling banyak diteruskan adalah informasi harga dan pembeli (98.46 persen). Hal ini dapat dimaklumi karena terkait dengan keuntungan yang akan diterima petani. Informasi pengendalian HPT diteruskan oleh 55.38 persen petani, karena banyak petani yang masih belum paham dan yakin dengan informasi pengendalian HPT yang dimiliknya dan yang dipraktekkannya. Informasi yang paling sedikit diteruskan adalah penjarangan buah (15.38 persen), karena banyak petani yang tidak mau menerapkannya dan takut petani lain mengalami kegagalan.

\section{Hubungan Penggunaan Sumber Informasi dengan Tingkat Pemanfaatan Informasi}

Penggunaan sumber informasi berhubungan sangat nyata dengan pemanfaatan informasi. Artinya semakin tinggi penggunaan sumber informasi (jumlah sumber informasi yang diakses, intensitas mengakses informasi, dan tingkat kesesuaian informasi) maka pemanfaatan informasi (untuk pengetahuan, dipraktekkan dan diteruskan kepada orang lain) akan semakin tinggi. Penelitian Hapsari (2012) menunjukkan bahwa jumlah sumber informasi berhubungan nyata dengan pemanfaatan informasi oleh petani. Asmawati (2013) menyatakan bahwa penggunaan sumber informasi berhubungan dengan pemanfaatan informasi dalam hal meningkatkan pengetahuan, tetapi tidak berhubungan 
dengan pemanfaatan untuk

dipraktekkan dan diteruskan kepada

orang lain.

Tabel 9 Hubungan penggunaan sumber informasi dengan tingkat pemanfaatan informasi

\begin{tabular}{lccc}
\hline Penggunaan sumber informasi & \multicolumn{3}{c}{ Pemanfaatan informasi } \\
\cline { 2 - 4 } & $\begin{array}{c}\text { Meningkatkan } \\
\text { pengetahuan }\end{array}$ & Dipraktekkan & $\begin{array}{c}\text { Diteruskan kepada } \\
\text { orang lain }\end{array}$ \\
\hline Jumlah sumber informasi & $0.641^{* *}$ & $0.697^{* *}$ & $0.713^{* *}$ \\
Intensitas mengakses informasi & $0.632^{* *}$ & $0.638^{* *}$ & $0.678^{* *}$ \\
Tingkat kesesuaian informasi & $0.473^{* *}$ & $0.422^{* *}$ & $0.487^{* *}$ \\
\hline
\end{tabular}

Keterangan: $\quad * *$ Berhubungan sangat nyata pada $\mathrm{p}<0.01$

\section{SIMPULAN}

1. Pemanfaatan informasi teknologi oleh petani mangga tergolong sangat tinggi untuk meningkatkan pengetahuan, sangat rendah untuk dipraktekkan, dan tinggi untuk diteruskan kepada orang lain.

2. Penggunaan sumber informasi oleh petani mangga adalah jumlah sumber informasi yang diakses sedikit dan intensitas mengakses informasi jarang, dan tingkat kesesuaian sumber informasi tinggi.

3. Karakteristik petani yang memiliki hubungan nyata dengan tingkat kebutuhan informasi adalah umur, tingkat pendidikan formal dan non formal, skala usaha dan pendapatan.

4. Faktor-faktor yang memiliki hubungan nyata dengan penggunaan sumber informasi adalah: (a) karakteristik petani, yaitu umur, tingkat pendidikan formal dan non formal, skala usaha dan pendapatan; (b) tingkat kebutuhan informasi, yaitu informasi budidaya, pasca panen, dan pemasaran; (c) tingkat akses informasi, yaitu kemudahan akses dan keterjangkauan biaya akses.
5. Semakin tinggi tingkat penggunaan sumber informasi maka semakin tinggi pula tingkat pemanfaatan informasi, baik dalam meningkatkan pengetahuan, dipraktekkan, maupun diteruskan kepada orang lain

\section{SARAN}

1. Perlu peningkatan intensitas kegiatan pendampingan dan pelatihan untuk meningkatkan pemanfaatan informasi teknologi khususnya untuk dipraktekkan dan diteruskan kepada orang lain.

2. Diseminasi informasi teknologi mangga agar memaksimalkan penggunaan sumber informasi yang sering digunakan petani mangga, yaitu petugas pertanian, sesama petani, buku, folder/poster, dan film/DVD dengan meningkatkan ketersediaan dan aksesibilitas informasi, serta meningkatkan kapasitas sumber informasi interpersonal.

3. Penyediaan informasi bagi petani mangga agar disesuaikan dengan hasil penilaian kebutuhan informasi petani.

4. Perlu upaya peningkatan penyebaran dan tingkat ketersediaan informasi 
bagi petani yang berumur tua, tingkat pendidikan rendah, skala usaha kecil, pendapatan rendah, tingkat kemudahan akses rendah dan biaya akses informasi tinggi agar tingkat penggunaan sumber informasi mereka dapat meningkat.

5. Perlu memberikan insentif kepada penyuluh yang mendampingi dan memberi pelatihan kepada petani.

\section{DAFTAR PUSTAKA}

Adedokun MO, Adeyemo CW, Olorunsola EO. 2010. The Impact of Communication on Community Development. $J$ Communication. 1(2):101-105.

Agunga R, Igodan C. 2007. Organic Farmers' Need for and Attitude Towards Extension. Journal of Extension (online). 45(6).

Andriaty E, Sankarto BS, Setyorini E. 2011. Kajian Kebutuhan Informasi Teknologi Pertanian di Beberapa Kabupaten di Jawa. Jurnal Perpustakaan Pertanian. 20(2):54-61.

Andriaty E, Setyorini E. 2012. Ketersediaan Sumber Informasi Teknologi Pertanian di Beberapa Kabupaten di Jawa. Jurnal Perpustakaan Pertanian. 21(1):30-35.

Asmawati. 2013. Pemanfaatan Hasil Penelitian Budidaya Tanaman Perkebunan dan Hortikultura Politeknik Pertanian Negeri Pangkajene dan Kepulauan [tesis]. Bogor (ID): Institut Pertanian Bogor.

Babu SC, Glendenning CJ, Kwadwo AO, Govindarajan SK. 2012. Farmers' Information Needs and Search Behaviors (Case Study in Tamil Nadu, India). Discussion Paper 01165. Eastern and Southern Africa
Regional Office. International Food Policy Research Institute (IFPRI).

Bardon RE, Hazel D, Miller K. 2007. Preferred Information Delivery Methods of North Carolina Forest Landowners Journal of Extension (online). 45(5).

[DJH] Direktorat Jenderal Hortikultura. 2013. Penerapan Teknologi Produksi Mangga. Jakarta (ID): Direktorat Jenderal Hortikultura Kementerian Pertanian.

Ellitan L, Anatan L. 2009. Manajemen Inovasi Transformasi Menuju Organisasi Kelas Dunia. Bandung (ID): Alfabeta.

[FAOSTAT] Food and Agriculture Organization Statistics. 2014. Production Quantities by Countries [internet]. [diunduh 1 Juli 2015]. tersedia pada http:/www.faostat3.fao.org/dow nload/T/TP/E.

Faroka FR, Seminar KB, Muljono P. 2013. Pengaruh Adopsi Teknologi PHSL (Pemupukan Hara Spesifik Lokasi) Berbasis Pertanian Presisi Terhadap Pendapatan Petani Padi di Desa Jembungan Kabupaten Boyolali Jawa Tengah. Jurnal Komunikasi Pembangunan. 11(1):1-13.

Hadiyanto. 2001. Perbandingan Perilaku Komunikasi Peternak di Desa Urban dan Desa Rural. Media Peternakan. 24(2):51-56.

Hapsari DR. 2012. Pemanfaatan Informasi oleh Petani Sayuran [tesis]. Bogor (ID): Institut Pertanian Bogor.

John O, Wakil O, Olateju A. 2013. Agricultural Information Needs of Farmers in Lagos. International Journal of 
Agricultural Science Research. 2(4):116-123.

Kifli GC. 2002. Perilaku Komunikasi Petani Padi dalam Penerapan Usahatani Tanaman Pangan [tesis]. Bogor (ID): Institut Pertanian Bogor.

Kifli GC. 2007. Strategi Komunikasi Pembangunan pada Komunitas Dayak di Kalimantan Barat. Forum Penelitian Agro ekonomi. 25(2):117-125.

Ma'mir M. 2001. Perilaku Petani Sayuran dalam Pemanfaatan Sumber Informasi Agribisnis Tanaman Sayuran di Kabupaten Kendari, Sulawesi Tenggara [tesis]. Bogor (ID): Institut Pertanian Bogor.

Moore N. 2007. Community Information and Technology Centres: Focus on South East Asia Bangkok: UNESCO [diunduh Mei 2014]. tersedia pada

http://portal.unesco.org/ci/en/file s/25659/11962595511telecentre _study_en.pdf/telecentre_study_ en.pdf.

Mulyadi, Sugihen BG, Asngari PS, Susanto D. 2007. Proses Adopsi Inovasi Pertanian Suku Pedalaman Arfak di Kabupaten Manokwari-Papua Barat. Jurnal Penyuluhan. 3(2):110-118.

Mulyandari RSH. 2011. Perilaku Petani Sayuran dalam Memanfaatkan Teknologi Informasi. Jurnal Perpustakaan Pertanian. 20(1):22-34.

Okwu OJ, Umoru BI. 2009. A Study of Women Farmers' Agricultural Information Needs and Accessibility: A Case Study of Apa Local Government Area of Benue State, Nigeria. African
Journal of Agricultural Research. 4(12):1404-1409.

Opara UN. 2008. Agricultural Information Sources Used by Farmers in Imo State, Nigeria. Information Development. 24(4):289-295.

Purnaningsih N, Ginting B, Slamet M, Saefuddin A, Padmowiharjo S. 2006. Faktor-Faktor yang Mempengaruhi Adopsi Inovasi Pola Kemitraan Agribisnis Sayuran di Jawa Barat. Jurnal Penyuluhan. 2(2):33-43.

Rifianto I. 2005. Mobilisasi Kelompok Tani dan Perencanaan Desa Partisipatif P4MI Badan Penelitian dan Pengembangan Pertanian.

Rogers E, Shoemaker F. 1995. Communication of Innovations: A Cross Cultural Approach. 3rd edition. New York (USA): The Free Press.

Saleh A, Mulyandari RSH. 2011. Pengembangan Pusat Informasi Pembangunan Pertanian Melalui Peningkatan Peran Radio Pertanian Ciawi dalam Komunikasi Inovasi Pertanian. Di dalam: Hamid F, et al. Ilmu Komunikasi Sekarang dan Tantangan Masa Depan. Jakarta (ID): Kencana-Prenada Media Group.

Saputra M. 2007. Kebijakan Kependudukan dan Keluarga Berencana dalam Jendela Kesempatan. Jurnal Warta Demografi. 37(1).

Thapa GB, Rattanasuteerakul K, 30:1-9. JoAG. 2010. Adoption and Extend of Organic Vegetatable Farming in Mahasarakhan Province, Thailand. Journal of Applied Geography. 30:1-9. 
Jurnal Komunikasi Pembangunan

ISSN 1693-3699

Juli 2014 Vol.12, No.2 